\title{
Evaluation of The National Urban Community Empowerment Program
}

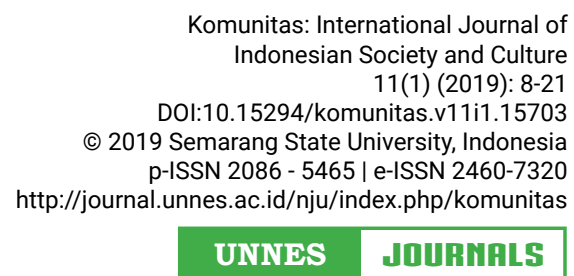

UNNDS

\section{Suparno ${ }^{1}$}

${ }^{1}$ Faculty of Social and Political Sciences, Universitas 17 Agustus 1945 Semarang, Central Java, Indonesia

Received: August 30, 2018; Accepted: March 1, 2018; Published: March 30, 2019

\begin{abstract}
The main problem of this research is the low community participation in the implementation of the Urban PNPM Mandiri in Grobogan Regency. This can be seen from the lack of community involvement in the entire process of the activity stage. The purpose of this study is to look at the level of community participation in the implementation of the Urban PNPM Mandiri in Grobogan Regency. The results of this study show that the implementation of the Urban PNPM Mandiri was good, the context of the implementation of the Urban PNPM Mandiri was good, the input of the Urban PNPM Mandiri was good, but the available funds were insufficient to meet community needs; the implementation process worked well, at the stage of preparation, community participation was low, especially in FGD on Poverty Reflection and Preparation of Medium-Term Planning for Poverty Reduction Programs (PJM Pronangkis); then the implementation of activities worked well and the products of activities of the Urban PNPM Mandiri in the form of physical activities benefited the community. Based on the findings, it is recommended that, the effectiveness of the Urban PNPM Mandiri needs to be improved; PNPM apparatus in regency level should be more democratic and participatory in the implementation of planned programs. Community involvement should always be encouraged in the entire processes and stages of activities, starting from planning, implementation, monitoring and evaluation, and in the preparation of reporting for each activity.
\end{abstract}

\section{Keywords}

policy evaluation; poverty reduction; program evaluation

\section{INTRODUCTION}

National development is an effort to reach communities that are prosperous, fair and wealthy as a step to advance the standard of living of communities who are materially and spiritually equal in accordance with the basic foundation of the Indonesian state, Pancasila and the 1945 Constitution of the Republic of Indonesia. The implementation of development is intended for all levels of community, both from urban areas to remote areas, because it has become a commit- ment of the Indonesian state government in equalizing development in all regions of Indonesia. Development goals to achieve government programs in the welfare of the lives of Indonesian people both in terms of economic, social, political and cultural. In an effort to achieve these targets, it is necessary to engage with the government

\footnotetext{
Corresponding author

Jl. Pemuda No.70, Pandansari, Semarang Tengah, Semarang, Central Java 50133

Email

suparno.untag.smg@gmail.com
} 
and community which is carried out continuously (The World Bank Indonesia, 2008, p. 11; Chrystanti and Wardati, 2011, p. 44; Ahmadi and Wiyanti, 2014, pp. 19-22).

The National Program of Mandiri Community Empowerment (PNPM Mandiri) is the basic framework and reference for implementing community-based poverty alleviation. PNPM Mandiri aims to improve welfare by involving the community. The work area of PNPM Mandiri covers sub-districts, remote areas and urban areas (Surya, 2011, p. 101; Ningrum, 2014, p. 1). Community empowerment aims to accelerate poverty reduction and open employment opportunities (Bancin, 2011, p. 179; Nihayah, 2015, p. 1).

The process of achieving development goals at the urban and remote levels, the efforts of the Regency Consultant Team and PNPM Devices of Grobogan Regency assisted by Urban Village Apparatus led by the Head of Urban Village (Lurah) in increasing community awareness to participate in the implementation of development are very important and to be effective and efficient ways in implementing development. The role of the urban village apparatus in generating and enhancing community participation in the midst of community selfishness is very important so that the implementation of sustainable development can work according to expectations. In the implementation of the Urban PNPM Mandiri in Grobogan Regency, encouraging the participation of the community is not easy to get a response or participation from the community, because the community has different characteristics and attitudes well as. This can be seen from the existence of contradictory and apathetic attitudes towards development activities, even though there are still many communities who are enthusiastic about the implementation of the development.

Enthusiasm and community participation have not been maximized in the implementation of the development of the program of the Urban PNPM Mandiri yet, so it should be improved. Community participation will determine the success of the development program implemented. So the need for a way or effort to make public participation aware of government policies implemented on the principle of mutual benefit so that development can be felt by the community.

In general, the implementation of the Urban PNPM Mandiri is not as expected yet. Some physical development is already quite good, but some are still lacking in building community awareness for healthy living behaviour, and caring for and making drainage in their own homes so that slums in urban areas are no longer exist. The success and failure of the implementation of development in urban areas are largely determined by the role and capabilities of the urban village in encouraging and mobilizing the community. Therefore the urban village apparatus must have the ability to mobilize and be able to influence the community so that they can be invited to collaborate and participate in the implementation of the development program by facilitation of Consultants and Apparatus in Regency level.

The problem of this research is why the results of the Urban PNPM Mandiri have not been able to increase community empowerment and mobilize the community at the urban village level yet. Some facts show that physical development has not been carried out maximally yet. There is still a lot of infrastructure development which has not matched the expectations of the community yet. The level of community attendance in urban village discussion is low. Several activities in Urban PNPM Mandiri are not followed by the community. The Urban PNPM Mandiri activities begin with the planning stage, which includes the FGD on Poverty Reflections, the Medium-Term Planning of Poverty Reduction Programs (PJM Pronangkis); then the implementation of activities, monitoring and evaluation of the results of activities, and preparation of reports. In the implementation of activities both in the form of physical and non-physical activities community involvement is low.

Previous research that was conducted in West Bandung Regency showed that community participation was still in the moderate category and benefits that were 
obtained in the fields of skills, knowledge, health, and income. Community participation in the planning, organizing, budgeting and evaluation stages. At the planning stage, the community had not actively participated yet, while at the implementation and supervision stage it seemed to increase by participating in carrying out activities and controlling the development of activities in the field (Bancin, 2011, p. 179).

Other research on the analysis of the performance of revolving funds of the PNPM Mandiri in Lubuk Begalung Subdistrict, Padang City showed that revolving funds could increase micro and small businesses, and increase the availability of cash and increase net income so that they could expand and develop their businesses. Other impacts of PNPM Mandiri in that area could improve the quality of housing, health, education and nutrition (Surya, 2011, p. 114).

Urban PNPM Mandiri in Sastrodirjan Village Pekalongan Regency included socialization, implementation of the cycle and training which had worked well by using the socio-cultural approach. Socio-cultural approaches were carried out by paying attention to religious aspects, gender and everyday community habits. The attitude and view of the community towards PNPM Mandiri in that area was very good, it was seen from the involvement of the role and the response to PNPM Mandiri was quite good. PNPM Mandiri was able to change the level of public awareness and improve understanding to take part in development even though it still needed to be improved. PNPM Mandiri was able to increase awareness to be responsible by participating in the development (Mubarak, 2010, p. 153).

PNPM Mandiri in Wonosobo Subdistrict, Tanggamus Regency involved KPMD so it could increase the role of citizens in the planning, implementation, monitoring and evaluation process. The community participates in decision making. The success of KPMD involvement needed to be applied to other PNPM Mandiri to increase the role of citizens because it had proven effective (Hadi, Effendi and Hasanudin, 2013, p. 71).
The Urban PNPM Mandiri in Pakisaji Subdistrict, Malang Regency showed differences in income after getting capital assistance of a revolving loan. The program of capital and education loan had a positive and significant effect on the poor. Age variability did not affect the income of the poor (Alffitri, 2014, pp. 1-15).

The Evaluation of National Program of Community Empowerment (PNPM) Mandiri aims to: (a) evaluate the results of the Urban PNPM Mandiri Program that has been implemented in Grobogan Regency and (b) provide recommendations on the implementation of poverty reduction programs specifically in encouraging communities to participate in various development activities in their region.

Performance assessment can be conducted by comparing the results achieved with the targets set. Assessment can produce component information in managerial processes that can be used as study material to improve efficiency, effectiveness and productivity of work (Widiyanto, Suryono and Retno, 2017, p. 22). The theoretical concepts used in this study include program evaluation, evaluation stages, and program evaluation models.

\section{Evaluation Program}

Evaluation Program is a systematic method for collecting, analyzing, and using the information to answer questions about projects, policies and programs, particularly about their effectiveness and efficiency. In both the public and private sectors, stakeholders often want to know whether the programs they are funding, implementing, voting for, receiving or objecting to are producing the intended effect. While Evaluation Program first focuses around this definition, important considerations often include how much the program costs per participant, how the program could be improved, whether the program is worthwhile, whether there are better alternatives, if there are unintended outcomes, and whether the program goals are appropriate and useful. Evaluators help to answer these questions, but the best way to answer the questions is for the evaluation 
to be a joint project between evaluators and stakeholders (Shakman Gene, 2010).

Meanwhile, experts at the University of Washington say that Evaluation is critical to making informed decisions about programs and services. We provide technical assistance, evaluation tools, and other support services as well as learning opportunities that can help build internal expertise for organizations and agencies evaluations (University of Washington, 2017).

\section{Evaluation Stage}

According to experts at the University of Washington, Evaluation Stage are six steps. The six steps of evaluation are as follows:

"Six Steps of Program Evaluation. Program planning and evaluation go together. These six steps can help put your organization on the right track for continuous quality improvement.

Step 1: Define your stakeholders. Your stakeholders are supporters, implementers, recipients, and decision-makers related to your program. Getting them involved early on will help you get different perspectives on the program and establish common expectations. This helps to clarify goals and objectives of the program you'll evaluate, so everyone understands its purpose.

Step 2: Describe the program. Taking the time to articulate what your program does and what you want to accomplish is essential to establishing your evaluation plan. Your descriptions should answer questions like: What is the goal of our program? Which activities will we pursue to reach our goal? How will we do it? What are our resources? How many people do we expect to serve?

Articulating the answers to those questions will not only help with accountability and quality improvement, but it will also help you promote the program to its beneficiaries.

Step 3: Focus the design of your evaluation. Evaluations can focus on process, means, resources, activities, and outputs. They can focus on outcomes or how well you achieved your goal. You may also choose to evaluate both process and outcomes.

As you begin formulating your eva- luation, think about the specific purpose of the evaluation-what questions are you trying to answer? How will the information be used? What information-gathering methods are best suited for collecting what our organization needs to know?

Step 4: Gather evidence. Qualitative and quantitative data are the two main forms of data you may collect. Qualitative data offers descriptive information that may capture experience, behavior, opinion, value, feeling, knowledge, sensory response, or observable phenomena. Three commonly used methods used for gathering qualitative evaluation data are: key informant interviews, focus groups, and participant observation.

Quantitative methods refer to information that may be measured by numbers or tallies. Methods for collecting quantitative data include counting systems, surveys, and questionnaires.

Step 5: Draw conclusions. This is the step where you answer the bottom-line question: Are we getting better, getting worse, or staying the same? Data comparisons show trends, gaps, strengths, weaknesses. You can compare evaluation data with targets set for the program, against standards established by your stakeholders or funders, or make comparisons with other programs.

Step 6: Present findings and ensure use. It is important that all the work you put into program evaluation gets used for quality improvement. When you present your findings and recommendations, it is important to know the values, beliefs, and perceptions of your group; build on the group's background and build on common ground; and state the underlying purpose for your recommendations before you get to the details." (Northwest Center for Public Health Practice University of Washington, 2017; Rossi, Lipsey and Henry, 2018).

Furthermore, according to Suharsimi Arikunto, evaluating a program is an activity intended to find out how far the success rate of the planned activities (Suharsimi, 1993, p. 297).

Evaluating the program is carried out with the aim of: a. Show program contri- 
butions towards achieving organizational goals. The evaluation results are important to develop a similar program elsewhere. $b$. Take a decision on the continuation of a program, whether the final program is continued, corrected or terminated. Judging from the purpose, which is to know the condition of something, then evaluating the program can be said to be one form of evaluative research (Mulyatiningsih, 2011, pp. 114-5).

In evaluating the program, evaluation instruments need to be established. Therefore in evaluating the research program in this case the evaluator needs to establish the indicators used in the program evaluation. There are striking differences between research and program evaluation as follows: a. In research activities, researchers want to know the description of something then the results are described, while in evaluating the program, the implementation wants to know how far the quality or condition of something as a result of program implementation after the data collected is compared with certain criteria or standards; b. In research activities, researchers are demanded by the formulation of the problem because they want to know the answers of the research, while in evaluating the program, the implementation wants to know the level of achievement of the program goals, and if the goals have not been achieved yet as determined, its implementation wants to know where the deficiencies are and why (Arikunto and Jabar 2009).

With the above description, it can be said that the evaluation of the program is evaluative research. Basically, evaluative research is intended to find out the end of a variety of policies, in the framework of defining 12 recommendations on past policies, which at the final goal is to determine the policy further.

\section{Program Evaluation Model}

Evaluation models with one another seem to vary, but the intent and purpose are the same, namely to carry out data collection activities or information relating to the object being evaluated. Furthermore, the information collected can be given to decision ma- kers in order to be able to precisely determine the follow-up regarding the program that has been evaluated.

Evaluation Model includes a. The Goal-Oriented Evaluation Model, developed by Tyler; b. The Goal-Free Evaluation Model, developed by Scriven; c. The Formative General Evaluation Model, developed by Michael Scriven; d. The Countenance Evaluation Model, developed by Stake; e. The Responsive Evaluation Model, developed by Stake; f. CSE-UCLA Evaluation Model, emphasizes "when" evaluations are carried out; g. The CIPP Evaluation Model, developed by Stufflebeam; h. Discrepancy Model, developed by Provus. The selection of the evaluation model to be used depends on the evaluation objectives (Arikunto and Jabar, 2009).

In evaluating the program of the Urban PNPM Mandiri, a system approach was used. A system approach is an approach that is conducted in covering all the processes that are implemented. CIPP Program Evaluation, the model used in this study is an evaluation model developed by Stufflebeam known as the CIPP Evaluation Model. CIPP stands for Context, Input, Process and Product. In the Applied Research Book by Endang Mulyatiningsih (2011: 126), it is suggested that CIPP evaluation is known as formative evaluation with the aim of making decisions and improving programs.

As an embodiment of government that can carry out main duties and in the framework of the realization of good governance, not only requires appropriate institutions, and professional apparatus, but also responsible leaders. Program evaluation is carried out by the leadership and on the leadership's initiative to obtain feedback for future program improvements. The implementation of government programs, especially the Urban PNPM Mandiri, needs to be evaluated by using predetermined indicators. Evaluation of the Urban PNPM Mandiri uses the CIPP evaluation model, evaluation that includes the Context, Input, Process and Product variables.

The context referred to in this study is the background when the program is 
implemented which includes government policy support, community support, socio-political, and economic situations. Furthermore, regarding input, evaluation of inputs is the initial input of the program of the Urban PNPM Mandiri in the form of resources and policies used to initiate the Urban PNPM Mandiri. While the Process stage is the implementation of Urban PNPM Mandiri starting from the preparation, implementation, monitoring, evaluation and reporting stages. While the last variable is the product. It is goods or services produced by the Urban PNPM Mandiri which includes physical and non-physical development, as well as the level of benefits for the target community.

\section{METHOD}

This research was a study using a qualitative descriptive approach that was combined with simple statistics. In this study, described the success rate of Urban PNPM Mandiri in Grobogan Regency until June 2018. the Urban PNPM Mandiri in Grobogan Regency was carried out in 17 villages in Purwodadi Subdistrict, Grobogan Regency. Data used were primary data and secondary data. Secondary data collection techniques used documentation techniques, while in primary data collection, questionnaires and interview guide techniques were used for respondents and informants. The subject of this study was the beneficiaries of the Program of the Urban PNPM Mandiri, both direct and indirect beneficiaries, including Urban Village Communities, Urban Village Apparatus and Community Leaders in 17 Urban Villages, who were directly or indirectly involved in the implementation of the Urban PNPM Mandiri. The number of samples as the object of research was taken as many as 102 respondents.

In collecting primary data, a questionnaire was used to interview respondents. Meanwhile, secondary data collection in the form of monographic data, reports, an urban village in numbers, was carried out using documentation techniques. Data that had been collected then processed, with the stages of data processing starting from the process of editing, tabulating, up to coding.

Data analysis was carried out in the form of descriptive analysis describing the level of leadership of the urban village and community participation in the implementation of the program of the Urban PNPM Mandiri. The qualitative descriptive analysis was conducted by describing the results of the research of each indicator and research variable.

\section{RESULT AND DISCUSSION}

In accordance with the problems which have been studied, the results of this study include: the context of the Urban PNPM Mandiri and evaluation of the Urban PNPM Mandiri in Grobogan Regency; they are described as follows:

\section{The Context of the Urban PNPM Man- diri}

Context Variables of the Urban PNPM Mandiri include indicators of government policy support, community support, socio-political, and economic situations. The results of the study related to government policy support in the Urban PNPM Mandiri in Grobogan Regency, the result of which was that government policy support in the urban PNPM Mandiri was in the high category. This is indicated by the results of the calculation of the average value of the percentage of government policy support amounting to $72.13 \%$ and at intervals of $60.00 \%-79.99 \%$ in the high category. Thus it can be said that government policy support is in the high category. The policy support is in the form of a Regent Regulation concerning the Implementation of the urban PNPM Mandiri in Grobogan Regency and the Regent's Decree concerning the implementation of the savings and loans business activities of the urban PNPM Mandiri. In addition, the policies of the Government and the Provincial Government of Central Java are also quite large in the form of general instructions and technical guidelines for the implementation of the urban PNPM Mandiri and management funding support for the mana- 
gement of the urban PNPM Mandiri at the Provincial and Regency /City levels.

The indicator that supports the high level of Government Policy support is the support of the Grobogan Regency government in implementing the Urban PNPM Mandiri. The support of the Grobogan Regency government in implementing the Urban PNPM Mandiri towards the high Urban PNPM Mandiri. The results show that the majority of respondents strongly agree are $50.98 \%$ if it is said that the support of the Grobogan Regency government in implementing the Urban PNPM Mandiri, and those who agree are $30.39 \%$, as shown in Table 1.

Table 1. The support of the Grobogan Regency Government in Implementing the Urban PNPM Mandiri

\begin{tabular}{llcc}
\hline No & $\begin{array}{c}\text { Answer } \\
\text { Category }\end{array}$ & $\begin{array}{c}\text { Fre- } \\
\text { quency }\end{array}$ & $\begin{array}{c}\text { Percen } \\
\text { tage }(\%)\end{array}$ \\
\hline $\mathbf{1}$ & Strongly Agree & 52 & 50,98 \\
2 & Agree & 31 & 30,39 \\
3 & $\begin{array}{l}\text { Neither Agree } \\
\text { nor Disagree }\end{array}$ & 9 & 8,82 \\
& Slightly & 7 & 6,86 \\
4 & Disagree & & \\
& Disagree & 3 & 2.94 \\
& Total & 102 & 100.00 \\
\hline
\end{tabular}

From the table above, it can be concluded that the support of the Grobogan Regency government for the implementation of the Urban PNPM Mandiri was high. The high level of support from the Grobogan Regency government was proof of the commitment of the Grobogan Regency government to advance its region through a program of development activities in the Urban PNPM Mandiri.

In addition to providing support from the Grobogan Regency government, the context for implementing the Urban PNPM Mandiri in Grobogan Regency is community and private support. The community and the private sector are also required to provide support in the implementation of the Urban PNPM Mandiri. The support of the community and the private sector can be seen in Table 2.

Table 2. The Support of the Community and Private Sector towards the Urban PNPM Mandiri

\begin{tabular}{llrr}
\hline No & $\begin{array}{c}\text { Answer } \\
\text { Category }\end{array}$ & $\begin{array}{c}\text { Fre- } \\
\text { quency }\end{array}$ & $\begin{array}{c}\text { Percen } \\
\text { tage (\%) }\end{array}$ \\
\hline 1 & Strongly Agree & 19 & 18,63 \\
2 & Agree & 44 & 43,14 \\
3 & Neither Agree & 27 & \\
& nor Disagree & & 26,47 \\
4 & Slightly Disagree & 9 & 8,82 \\
5 & Disagree & 3 & 2,94 \\
\hline & Total & 102 & 100.00 \\
\hline
\end{tabular}

Based on Table 2, it can be concluded that the support of the community and the private sector for the implementation of the Urban PNPM Mandiri was high. This high level of the support of the community and the private sector was proof that the community and the private sector were providing support in the implementation of the Urban PNPM Mandiri. The support was in the form of high community participation at the urban village level and high levels of community self-help. The private sector helped by providing sharing in building infrastructure in urban village areas in Grobogan Regency.

In addition to providing the support of the Grobogan Regency government and the community and the private, the context of the implementation of the Urban PNPM Mandiri in Grobogan Regency was social and political economic conditions when the program was running. Based on observations during the research, the informant said that the socio-political conditions in Grobogan District were quite conducive and supported the smooth implementation of the Urban of PNPM Mandiri activities. During the implementation of the Urban PNPM Mandiri activities in Grobogan Regency, there were no disturbances from either the community or mass organizations or political parties that could derail the implementation of the Urban PNPM Mandiri. Meanwhile, economic conditions also sufficiently supported the implementation of the Urban PNPM Man- 
diri. The inflation rate during the implementation of PNPM Mandiri Urban ranged from $2.1 \%-3.2 \%$. While economic growth ranged from $5.1 \%$ in 2018 . While the national economy was also relatively stable and unstable, thus supporting the implementation of the Urban PNPM Mandiri.

\section{Input Evaluation of the Urban PNPM Mandiri}

Inputs in the implementation of the Urban PNPM Mandiri were in the form of resources and policies. Resources included human resources, methods, funds, equipment and materials. Meanwhile, policies in the form of policies relating to regulations, implementation guidelines, technical instructions and recommendations for the implementation of certain activities. An evaluation of inputs was related to the adequacy of inputs to achieve PNPM's objectives in Grobogan Regency.

The results of the evaluation of the Urban PNPM Mandiri input in Grobogan Regency showed that input in the implementation of the Urban PNPM Mandiri was in the high category. This is indicated by the calculation of the average value of the input percentage of the Urban PNPM Mandiri of $69.57 \%$ and is in the interval of $60.00 \%$ $79.99 \%$ in the high category. Thus it can be said that the input to the implementation of the Urban PNPM Mandiri is in the high category.

Evaluation of inputs relates to resources and policies. Evaluation of resources uses indicators of adequacy and quality of inputs in supporting the success of the implementation of the Urban PNPM Mandiri. Evaluation results indicate that the input is sufficient in the form of human resources consisting of provincial management consultants, regency management consultants, and facilitators according to respondents. Most respondents say that the amount of available human resources is sufficient (40.20\%) and very sufficient (20.59\%). This is shown in Table 3.

Based on the table 3, it can be stated that the input in the form of human resources was sufficient for the implementation of the Urban PNPM Mandiri in Grobogan Regency. This meant that the human resources provided for the implementation of PNPM Mandiri Urban from the provincial and district levels as well as facilitators were sufficient.

Table 3. The adequacy of Human Resources for the Implementation of the Urban PNPM Mandiri in Grobogan Regency

\begin{tabular}{llrr}
\hline No & Answer Category & $\begin{array}{c}\text { Fre- } \\
\text { quency }\end{array}$ & $\begin{array}{c}\text { Percen } \\
\text { tage }(\%)\end{array}$ \\
\hline 1 & Very Sufficient & 15 & 14,71 \\
2 & Sufficient & 41 & 40,20 \\
3 & Sufficient enough & 21 & 20,59 \\
4 & Slightly Sufficient & 17 & 16,67 \\
5 & Insufficient & 8 & 7,84 \\
\hline & Total & 102 & 100.00 \\
\hline
\end{tabular}

Apart from the number aspect, from the aspect of quality or competency of human resources, an evaluation is also carried out. The evaluation results show that most respondents say that they agree that human resource competency is good $(50.98 \%)$. In detail, the respondents receive the quality of human resources as shown in Table 4.

Table 4. The Quality of the Implementing Resources of the Urban PNPM Mandiri

\begin{tabular}{llrr}
\hline No & $\begin{array}{c}\text { Answer } \\
\text { Category }\end{array}$ & $\begin{array}{r}\text { Frequen- } \\
\text { cy }\end{array}$ & $\begin{array}{r}\text { Percentage } \\
(\%)\end{array}$ \\
\hline 1 & Very Good & 16 & 15,69 \\
2 & Good & 52 & 50,98 \\
3 & Enough & 23 & 22,55 \\
4 & Slightly Good & 9 & 8,82 \\
5 & Bad & 2 & 1,96 \\
\hline & Total & 102 & 100.00 \\
\hline
\end{tabular}

From table 4, it can be stated that input quality was good in the form of quality human resources. This meant that Urban PNPM Mandiri was carried out by people who had good qualifications and competencies. Good quality of human resources was a guarantee that later the implementation of urban PNPM Mandiri will gain good results.

In addition to human resources, other inputs are in the form of funds. Funds or 
financing are one of the vital inputs in the implementation of the Urban PNPM Mandiri. The available funds are actually only stimulants and are expected to be self-help funds so that the results obtained are more optimal. The results of the evaluation state that the funds provided by the government in implementing the Urban PNPM Mandiri are insufficient. Most respondents say that the data available is insufficient. In detail, the opinions of respondents regarding the availability of funds can be seen in Table 5 .

Table 5. The Adequacy of the Funds of the Urban PNPM Mandiri in Grobogan Regency

\begin{tabular}{llrr}
\hline \multirow{2}{*}{ No } & Answer Category & $\begin{array}{c}\text { Fre- } \\
\text { quency }\end{array}$ & $\begin{array}{c}\text { Percen } \\
\text { tage (\%) }\end{array}$ \\
\hline 1 & Very Sufficient & 2 & 1,96 \\
2 & Sufficient & 27 & 26,47 \\
3 & Sufficient enough & 19 & 18,63 \\
4 & Slightly Sufficient & 33 & 32,35 \\
5 & Insufficient & 21 & 20,59 \\
\hline & Total & 102 & 100,00 \\
\hline
\end{tabular}

From the table, it appeared that the input in the form of funds for the purposes of implementing the UrbanPNPM Mandiri especially funds for the community was insufficient. This meant that Urban PNPM Mandiri was implemented with insufficient funding to meet community needs. Conditions indicated that community selfhelp or community participation in the form of funds was still lacking.

Meanwhile, for the input of the Urban PNPM Mandiri in the form of material, facilities and infrastructures according to the evaluation results, it is sufficient. The availability of materials, facilities, and infrastructures according to the respondent's information is sufficient, which is $51.96 \%$. In detail, the respondents' opinions about the availability of resources in the form of infrastructures and materials can be seen in Table 6.

Meanwhile, the input of the Urban PNPM Mandiri in the form of policy according to the respondent's information and the results of observations in the field indicated that it was sufficient. The policy of the Regency Government in implementing the UrbanPNPM Mandiri was sufficient to support the implementation of the Urban PNPM Mandiri in Grobogan Regency.

Table 6. The availability of materials, facilities, and infrastructures

\begin{tabular}{llrr}
\hline No & Answer Category & $\begin{array}{c}\text { Fre } \\
\text { quency }\end{array}$ & $\begin{array}{c}\text { Percen } \\
\text { tage (\%) }\end{array}$ \\
\hline 1 & Very Sufficient & 24 & 23,53 \\
2 & Sufficient & 53 & 51,96 \\
3 & Sufficient Enough & 16 & 15,69 \\
4 & Slightly Sufficient & 7 & 6,86 \\
5 & Insufficient & 2 & 1,96 \\
\hline & Total & 102 & 100,00 \\
\hline
\end{tabular}

The Evaluation of the Process of Implementing the Urban PNPM Mandiri

The result of the evaluation of the implementation process of the Urban PNPM Mandiri in Grobogan Regency as a whole, the implementation process of the UrbanPNPM Mandiri was included in the high category. This is indicated by the calculation of the average value of the percentage of the implementation process of the Urban PNPM Mandiri in the amount of $73.33 \%$ and in the interval of $60.00 \%-79.99 \%$ in the high category. This condition shows that the implementation process of Urban PNPM Mandiri in Grobogan Regency is working well. The implementation process of the Urban PNPM Mandiri covers the stages of preparation, implementation, monitoring, evaluation and reporting. Thus starting from the preparatory stage to the reporting of implementation PNPM Mandiri Urban is working well.

The contribution of the indicators in the evaluation process is an evaluation of the preparation process for implementing the Urban PNPM Mandiri activities. Preparations for the Urban PNPM Mandiri in Grobogan Regency included information dissemination activities, preparation PJM Pronangkis of the urban village, mapping of the poor, and preparation of community work plans. Based on the evaluation conducted, the process at the preparation stage can run very well. The results of 
the calculation of the average percentage value are $89.87 \%$ and in the interval of $80.00 \%-100.00 \%$ in the very high category. Conditions illustrate that almost all stages in the preparation of PNPM Mandiri Urban implementation are going very well.

In the preparation process, the preparation of the PJM Pronangkis and the Community Work Plan need to get attention. According to information, respondents in the preparation of PJM Pronangkis are less participatory. Based on the evaluation results, most respondents say that the preparation of the PJM Pronangkis is less participatory as much as $43.14 \%$ of respondents. In detail, the opinions of respondents regarding the preparation of the Pronangkis can be seen in Table 7.

Based on table 7 , it can be stated that the level of community participation in the preparation of PJM Pronangkis was lacking. The community is not much involved in the process of preparing PJM Pronangkis, which should be based on the principle of participation. Philosophically, the process of preparing PJM Pronangkis did not fullfil the requirements.

Table 7. The Preparation Process of the PJM Pronangkis

\begin{tabular}{llrr}
\hline No & $\begin{array}{c}\text { Answer } \\
\text { Category }\end{array}$ & $\begin{array}{r}\text { Frequen- } \\
\text { cy }\end{array}$ & $\begin{array}{r}\text { Percentage } \\
(\%)\end{array}$ \\
\hline 1 & Very Good & 8 & 7,84 \\
2 & Good & 14 & 13,73 \\
3 & Good Enough & 27 & 26,47 \\
4 & Slightly Good & 44 & 43,14 \\
5 & Bad & 9 & 8,82 \\
\hline & Total & 102 & 100 \\
\hline
\end{tabular}

Before the preparation of the PJM Pronangkis, a community poverty mapping is prepared in advance. The preparation of poverty mapping also needs to be done to identify poor people in each urban village. The preparation of this poverty mapping is carried out by the community in a democratic and participatory manner by facilitating the urban village apparatus and facilitators of the Urban PNPM Mandiri. The evaluation results obtain information that the preparation of the mapping according to the majority of respondents carried out is less democratic as much as $47.06 \%$. In detail, the information from respondents is seen in Table 8.

Table 8. Democratic Poverty Mapping Preparation

\begin{tabular}{llrr}
\hline No Answer Category & \multicolumn{1}{c}{$\begin{array}{c}\text { Fre- } \\
\text { quency }\end{array}$} & $\begin{array}{r}\text { Percentage } \\
(\%)\end{array}$ \\
\hline 1 & Very Democratic & 7 & 6,86 \\
2 & Democratic & 22 & 21,57 \\
3 & $\begin{array}{l}\text { Democratic } \\
\text { Enough }\end{array}$ & 21 & 20,59 \\
4 & Slightly Demo- & & \\
& cratic & 48 & 47,06 \\
5 & Undemocratic & 4 & 3,92 \\
\hline & Total & 102 & 100.00 \\
\hline
\end{tabular}

From the table, it appeared that the preparation of the mapping was carried out less democratically. Based on information from informants, the preparation of poverty mapping was dominated by urban village officials and RT and RW. Determination of poor criteria was also determined by the urban village not based on community input.

The contribution of the indicators in the evaluation process is an evaluation of the process of implementing the Urban PNPM Mandiri activities. The implementation of the Urban PNPM Mandiri in Grobogan Regency includes infrastructure development activities (physical work) and the implementation of non-physical activities. Based on the evaluation carried out, the process at the stage of implementation of the activities can run very well. The results of the calculation of the average percentage value are $81.29 \%$ and in the interval of $80.00 \%$ $100.00 \%$ in the very high category. Conditions illustrate that almost all stages in the implementation of PNPM Mandiri Urban are going very well.

In the implementation stage which gives a major contribution to the success of the implementation is the implementation of physical development, for example, the construction of drainage, sanitation, village roads and sewers. According to 
most respondents, they say that physical development carried out is appropriate with plan. In detail, information relating to the opinions of respondents regarding the implementation of physical development can be seen in Table 9 .

Table 9. The Physical Development in accordance with the Plan

\begin{tabular}{llrr}
\hline No & Answer Category & \multicolumn{1}{c}{$\begin{array}{c}\text { Fre- } \\
\text { quency }\end{array}$} & $\begin{array}{c}\text { Percen } \\
\text { tage (\%) }\end{array}$ \\
\hline $\mathbf{1}$ & Very Appropriate & 59 & 57,84 \\
2 & Appropriate & 27 & 26,47 \\
3 & Appropriate & & \\
& Enough & 11 & 10,78 \\
4 & Slightly Appropri- & & \\
& ate & 3 & 2,94 \\
5 & Inappropriate & 2 & 1,96 \\
\hline & Total & 102 & 100.00 \\
\hline
\end{tabular}

The data in table 9 meant that the implementation of physical development in the context of implementing the Urban PNPM Mandiri was in accordance with the plan. Physical development in the form of building environmental roads, sewers and drainage were appropriate with what was planned by the community.

\section{The Evaluation of Product of the Ur- ban PNPM Mandiri}

The evaluation of the Product of the UrbanPNPM Mandiri urban was an evaluation of the results of the Urban PNPM Mandiri in Grobogan Regency. The results of the implementation of the Urban PNPM Mandiri were divided into two groups, namely the results of physical work and the results of non-physical work. The results of PNPM Mandiri Urban in the form of building village roads, water tunnels, gutters, gutters divider by road, Posyandu buildings and Kamling Post. While the results of non-physical activities were the Savings and Loans unit managed by women, urban village health posts, poverty alleviation cadres training, health cadres training, community economic empowerment (training and mentoring) and urban village apparatus empowerment (work plan preparation).
The results of the evaluation of the product of the Urban PNPM Mandiri show that the assessment of the quality and quantity of results or outcomes of the Urban PNPM Mandiri activities in Grobogan Regency is included in the high category. This is indicated by the results of the calculation of the average percentage value for product quality and quantity of Urban PNPM Mandiri is $74.29 \%$ and in the intervals of $60.00 \%$ $-79.99 \%$, in the high category. This condition shows that the product or activity results in implementing the Urban PNPM Mandiri in Grobogan Regency are good and have benefits for the community. The results of the evaluation of physical activities are obtained from the results that physical activities on average fulfill the specified criteria. On average the assessment of physical activities is in a good category. The achievement of the evaluation of physical activities is $76.91 \%$ including the high category. Some indicators show high contribution is the level of the advantage of the results of physical activity for the community. Most respondents state that the construction of village roads is beneficial for the community, amounting to $56.86 \%$. The community opinion in detail can be seen in Table 10.

Table 1o. The Advantage of the Village Road Development

\begin{tabular}{clrr}
\hline \multirow{2}{*}{ No } & $\begin{array}{c}\text { Answer } \\
\text { Category }\end{array}$ & $\begin{array}{c}\text { Fre- } \\
\text { quency }\end{array}$ & $\begin{array}{c}\text { Percen } \\
\text { tage }(\%)\end{array}$ \\
\hline $\mathbf{1}$ & Very Advanta- & & \\
& geous & 12 & 11,76 \\
2 & Advantageous & 58 & 56,86 \\
3 & Advantageous & & \\
& Enough & 23 & $\mathbf{2 2 , 5 5}$ \\
4 & Advantageous & 6 & 5,88 \\
5 & Disadvantageous & 3 & $\mathbf{2 , 9 4}$ \\
\hline & Total & 102 & 100.00 \\
\hline
\end{tabular}

The table meant that the advantages of village road development had profits for the community. Based on observations in the field, the construction of village roads can improve the economy of the community. Communities in carrying out economic 
activities were more smoothly compared to before. In addition, the selling price of agricultural products was better, because farmers had a better bargaining position.

While the overall evaluation of nonphysical activities reaches an average score of $64.77 \%$, including the high category. Achievement of evaluation of non-physical activities, although including high categories but closer to the lower limit, so it is not optimal. Non-physical activities that contribute to the results of the evaluation have not been optimal yet are savings and loan activities managed by women. The results of evaluations of savings and loan activities or the Savings and Loans Unit managed by women. A large number of respondents say that there are $41.18 \%$ of respondents who are unactive. In detail, the opinions of the respondents are shown in Table 11.

From the table, it can be stated that the results of the Urban PNPM Mandiri activities in the form of non-physical activities, namely the Savings and Loans Unit (USP) managed by women had not been active so that the benefits for the community were lacking. Based on observations in the field, the inactivity of savings and loan activities is a result of the active participation of members to repay loans that they had borrowed.

Table 11. The Savings and Loans Unit (USP) managed by women

\begin{tabular}{llrr}
\hline No & Category & \multicolumn{1}{c}{$\begin{array}{c}\text { Fre } \\
\text { quency }\end{array}$} & \multicolumn{1}{c}{$\begin{array}{c}\text { Percen } \\
\text { tage }(\%)\end{array}$} \\
\hline 1 & Very Active & 2 & 1,96 \\
2 & Active & 19 & 18,63 \\
3 & Fair & 28 & 27,45 \\
4 & Unactive & 42 & 41,18 \\
5 & Very Unactive & 11 & 10,78 \\
\hline & Total & 102 & 100.00 \\
\hline
\end{tabular}

\section{CONCLUSION}

Based on the results of the research described, it can be concluded that the overall implementation of the Urban PNPM Mandiri in Grobogan Regency based on the results of evaluations using the CIPP model was included in the high category. the support of the community, government and private sector for the implementation of the Urban PNPM Mandiri was high. This high level of the support of the community, government and private was proof that the community and the private sector were providing support in the implementation of the Urban PNPM Mandiri. The support was high in the form of high community participation at the urban village level and the community self-help level. The private sector helped by providing sharing in building infrastructure in urban villages in Grobogan Regency. As such, the implementation of the Urban PNPM Mandiri in Grobogan Regency was taking place or was well implemented or had been successful in providing benefits to the community. The more complete elements of success were as follows:

a. The results of the study related to the support of the government policy in the Urban PNPM Mandiri in Grobogan Regency was gained the result of which was that the support of the government policy in the Urban PNPM Mandiri was in the high category. This was indicated by the results of the calculation of the average present value of government policy support was $72.13 \%$ and at the intervals of $60.00 \%$ $-79.99 \%$ in the highest category. Thus it can be said that government policy support was in the high category;

b. The results of the evaluation of the Urban PNPM Mandiri inputs in Grobogan Regency showed that input in the implementation of the Urban PNPM Mandiri was in the high category. This was indicated by the results of interest in the average percentage of the urban PNPM Mandiri input was $69.57 \%$ and at the intervals of $60.00 \%-79.99 \%$ in the high category. Thus it can be said that the input in the implementation of the Urban PNPM Mandiri was in the high category;

c. The result of the evaluation of the implementation process of the Urban PNPM Mandiri in Grobogan Regency as a whole, the implementation of the Urban PNPM Mandiri was included 
in the high category. This was indicated by the results of the calculation of the average value of the process of implementing the Urban PNPM Mandiri was $73.33 \%$ and at the intervals of $60.00 \%-79.99 \%$ in the highest category. This condition showed that the implementation process of theUrban PNPM Mandiri in Grobogan Regency was working well;

$\mathrm{d}$. The results of the evaluation of the Urban PNPM Mandiri Product showed that the assessment of the quality and quantity of results or outcomes of the Urban PNPM Mandiri activities in Grobogan Regency was included in the high category. This was indicated by the results of the calculation of the average value of the product quality and quantity of Urban PNPM Mandiri amounting to $74.29 \%$ and at intervals of $60.00 \%-79.99 \%$ in the high category. This condition showed that the product or activity results in implementing the Urban PNPM Mandiri in Grobogan Regency were good and had benefits for the community.

\section{RECOMMENDATION}

Based on the conclusions of this study, the recommendations are as follows:

a. In the implementation of the preparatory activities, the community was not involved in the planning of activities, namely in the preparation of the PJM Pronangkis and Mapping of Poverty, in the next implementation, the community participation should be increased with more increased community involvement in each planning activity;

b. The results of the evaluation of inputs were obtained information that the available funds were insufficient to finance all activities, based on these results, it is suggested that funds in the Urban PNPM Mandiri are stimulant funds, therefore in the future, facilitators and communities should raise community self-help funds so that development outcomes more optimal; c. The Savings and Loans Unit managed by women needs serious assistance and firmness in their management so that the benefits of this unit can be optimized for the community;

$\mathrm{d}$. The community should always monitor, evaluate the implementation of the program starting from the stage of the planning to the preparation of financial reporting in order to avoid misuse of the budget for the implementation of transparent and accountable development.

\section{REFERENCES}

Ahmadi, A. and Wiyanti, D. T. (2014) 'Implementasi Weighted Product ( WP ) dalam Penentuan Penerima Bantuan Langsung Masyarakat PNPM Mandiri Perdesaan', in Seminar Nasional Aplikasi Teknologi Informasi (SNATI), pp. 19-22.

Alffitri, R. (2014) 'Program Nasional Pemberdayaan Masyarakat ( PNPM ) Mandiri Perkotaan', Jurnal Ilmiah Mahasiswa FEB, 2(2).

Arikunto, S. and Jabar, C. S. A. (2009) Metode Evaluasi Kebijakan. Yogyakarta: Bina Aksara.

Bancin, M. H. (2011) 'Peningkatan Partisipasi Masyarakat Dalam Program Nasional Pemberdayaan Masyarakat (PNPM) Mandiri Perdesaan (Studi Kasus: Bandung Barat)', Jurnal Perencanaan Wilayah dan Kota, 22(3), pp. 179-194.

Chrystanti, yulanita cahya and Wardati, I. ulli (2011) 'Sistem Pengolahan Data Simpan Pinjam khusus Perempuan (SPP) Pada Unit Pengelola Kegiatan (UPK) Mitra Usaha Mandiri Program Nasional Pemberdayan Masyarakat Mandiri Perdesaan (PNPM-MPd) Kecamatan Pringkuku Kabupaten Pacitan Yulanita Cahya Chrystanti, Indah', Joural Speed-Sentra Penelitian Engineering dan Edukasi, 3(1), p. 61.

Hadi, A. R., Effendi, I. and Hasanudin, T. (2013) 'Peranann Kader pemberdayaan masyarakat Desa (KPMD) dan partisipasi masyarakat pada program nasional pemberdayaan masyarakat mandiri pedesaan (PNPM-MP) di Kecamatan Wonosobo Kab. Tanggamus', Jurnal Ilmu-Ilmu Agribisnis, 1(1), pp. 66-72.

Mubarak, Z. (2010) Evaluasi Pemberdayaan Masyarakat Ditinjau dari Proses Pengembangan Kapasitas dapa Kegiatan PNPM Mandiri Perkotaan, Thesis Magister Teknik Pembangunan Wilayah dan Kota UNDIP, Semarang. Universitas Diponegoro. Available at: http://eprints.undip. ac.id/23734/.

Mulyatiningsih, E. (2011) Evaluasi Program Pembangunan Daerah. Yogyakarta: Pustaka Pelajar.

Nihayah, A. Z. (2015) 'Pengaruh Program Simpan Pinjam Kelompok Perempuan terhadap Pendapa- 
tan Saha Mikro Kecil dan Poverty Reduction dalam Perspektif Ekonomi Islam', Economic: Jurnal Ekonomi dan Hukum Islam, 5(2), pp. 1-24.

Ningrum, H. A. (2014) 'Partisipasi Masyarakat dalam Program Nasional Pemberdayaan Masyarakat Mandiri', eJournal Sosiologi, 2(3), pp. 1-24.

Northwest Center for Public Health Practice University of Washington (2017) Six Steps of Program Evaluation.

Rossi, P. H., Lipsey, M. W. and Henry, G. T. (2018) Evaluation: A systematic approach. Sage publications.

Suharsimi, A. (1993) 'Prosedur Penelitian Suatu Pendekatan Praktek, Jakarta: PT', Rineka Cipta.

Surya, S. (2011) 'Analisis Kinerja Dana Bergulir PNPM Mandiri di Kecamatan Lubuk Begalung Kota
Padang, Jurnal Administrasi Bisnis, 7(2), pp. 101-117. Available at: http://journal.unpar. ac.id/index.php/JurnalAdministrasiBisnis/article/viewFile/406/39o.

The World Bank Indonesia (2008) Impact Evaluation of the Second Phase of the Kecamatan Development Program in Indonesia. Jakarta: The World Bank Indonesia.

University of Washington (2017) Evaluation Services for Public Health, University of Washington. Available at: https://www.nwcphp.org/communications/news/nwcphp-to-evaluate-newprogram-targeting-pediatric-mental-health.

Widiyanto, Suryono and Retno, K. (2017) Sistem Informasi Pengukuran Kinerja Unit Pengembang Jurnal dengan Metode Analytical Hierarchy Process (AHP). Universitas Diponegoro. Available at: http://eprints.undip.ac.id/56102/. 